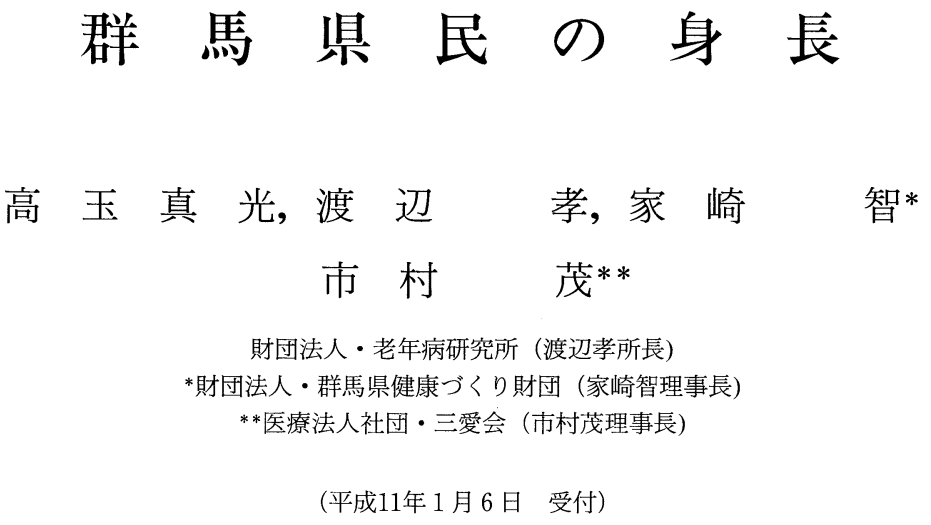

\begin{abstract}
要 旨：群馬県下 46 地区の集団検診成績から，40歳以降の身長が高い地区と低い地区とを明らかにした が, 全国平均を上回って高身長を呈する地区はない.群馬県民の平均身長は 40 歳代から 80 歳以上の何れの年 齢層も全国平均を下回っている. しかし全国平均との差は 70 歳以降の群に比べ 40 歳代では縮小しており, 幼稚園児から高校生にかけての身長は全国平均並みであるところから，身長に影響を与える社会経済的要因 は過去の時代に逆上るほど群馬県では全国との相違が大きかったものと思われる. しかし将来は当県の成人 身長が全国平均並みに達するものと期待される.なお，全国平均の乳幼児身長は昭和 55 年以降の伸びが目立 たないが,これは，この間における乳幼児期の栄養摂取状況に大きな変化がなかったことを暗示している.

また, 5〜 17 歳の身長を都道府県別にみると西低東高の様相を呈しているが, これには気象条件が影響して いるものと思われる.
\end{abstract}

Key words : 身長, 疫学

(Kitakanto Med.J. 49 (2) : 109 116, 1999)

は じめに

群馬県民の身長に関しては, 40～69 歳についての調査 で，男女とも全国平均より低いことを報告ずみである11. 今回は平成 5 年から平成 8 年に至る 4 年間の集団検診成 績を過去の調査成績に加え, 当県における 40 歳以降の 身長を全国平均と比較するとともに, 県内の高身長地区 と低身長地区を明らかとた，また各年噛層における全国 平均身長の年次推移を検討するとともに, 児童・生徒の 身長と気象との関連について検討した。

\section{方法}

集団検診は, 健康づくり財団が 32 地区 (4 市, 14 町, 14 村), 三愛会が 14 地区 (9町, 5 村) を担当した. 県内各地 区の身長を検討するにあたっては, 平成 $7 〜 8$ 年の 2 年 間の成績を一括平均した. 被験者数は男 68,827 名, 女 124,914 名である.

昭和 55 年度から平成 8 年度にかけての身長の推移に ついては, 群馬県の成績は成人病研究所の資料 ${ }^{11}$ を加え,
全国平均には国民栄養調査の成績2)を用いた。

なお近年における 5〜17 歳の身長については, 学校保 健統計調査 3,4$)$ を資料とした.

\section{成績}

\section{1. 群馬県内の検討}

被験者数が少ない地区の成績は，検診年度の違いによ る数值の変動が大きい嫌いがあるので, ここでは平成 7 年度と平成 8 年度の 2 年間の成績を一括して検討した.

40 歳代から 80 歳以上にかけての年歯階級 5 区分のう ち 4 区分以上で県平均值より有意差を示す地区をみる と, 男の身長が高いのは安中市, 低いのは昭和村, 利根村 である．そのほか年齢階級 3 区分ともに有意差を呈する 地区を含めた結果を表 1 に示した. 一方, 女では新町, 渋 川市, 安中市, 群馬町, 吉井町の身長が高く, 利根村, 片品 村, 高山村, 板倉町, 昭和村, 白沢村, 沼田市, 月夜野町, 千 代田町の身長は低い. なお年齢階級 3 区分ともに有意差 を呈する地区を含めた結果を表 2 に示した.

これによると, 男女ともに身長が高いのは渋川市, 安 
表 1 男の身長 (一印は集検対象としなかった年齢層)

\begin{tabular}{|c|c|c|c|c|c|c|}
\hline & 地 区 名 & 40〜49 歳 & $50 \sim 59$ 歳 & $60 \sim 69$ 歳 & $70 \sim 79$ 歳 & $80 \sim 89$ 歳 \\
\hline 高 い 地 区 & $\begin{array}{llll}\text { 渋 } & \text { 川 } & \text { 市 } \\
\text { 安 } & \text { 中 } & \text { 市 } \\
\text { 新 } & & & \text { 町 } \\
\text { 大 } & \text { 間 } & \text { 々 } & \text { 町 }\end{array}$ & $\begin{array}{l}166.9 \\
167.6^{* * *} \\
168.3^{* * *} \\
167.3^{* *}\end{array}$ & $\begin{array}{l}163.4 \\
163.7^{* *} \\
163.4 \\
164.3^{* * *}\end{array}$ & $\begin{array}{l}161.8^{* * *} \\
161.3^{* * *} \\
162.1^{* * *} \\
161.5^{* * *}\end{array}$ & $\begin{array}{c}159.2^{* * *} \\
159.1^{* * *} \\
161.1^{* * *} \\
-\end{array}$ & $\begin{array}{l}156.0^{* *} \\
156.4^{* * *} \\
- \\
-\end{array}$ \\
\hline 地 & 平 & 166.7 & 163.1 & 160.4 & 157.8 & 154.8 \\
\hline 低 い 地 区 & $\begin{array}{ccc}\text { 沼 } & \text { 田 } & \text { 市 } \\
\text { 月 } & \text { 夜 野 } & \text { 町 } \\
\text { 赤 } & \text { 城 } & \text { 村 } \\
\text { 高 } & \text { 山 } & \text { 村 } \\
\text { 利 } & \text { 根 } & \text { 村 } \\
\text { 昭 } & \text { 和 } & \text { 村 } \\
\end{array}$ & $\begin{array}{l}166.6 \\
166.4 \\
165.7^{* * *} \\
166.4 \\
165.8^{* *} \\
165.7^{* * *}\end{array}$ & $\begin{array}{l}162.9^{*} \\
162.0^{* *} \\
162.5 \\
161.9^{*} \\
162.2^{*} \\
161.2^{* * *}\end{array}$ & $\begin{array}{c}159.1^{* * *} \\
159.8^{* *} \\
159.3^{* * *} \\
159.1^{* * *} \\
159.1^{* * *} \\
159.3^{* * *}\end{array}$ & $\begin{array}{l}156.6^{* * *} \\
157.1^{*} \\
157.2^{*} \\
156.6^{* *} \\
156.3^{* * *} \\
156.6^{* * *}\end{array}$ & $\begin{array}{l}153.2^{* * *} \\
155.3 \\
154.0 \\
154.1 \\
154.8 \\
153.1^{* *}\end{array}$ \\
\hline
\end{tabular}

表 2 女の身長 (一印は集検対象としなかった年齢層)

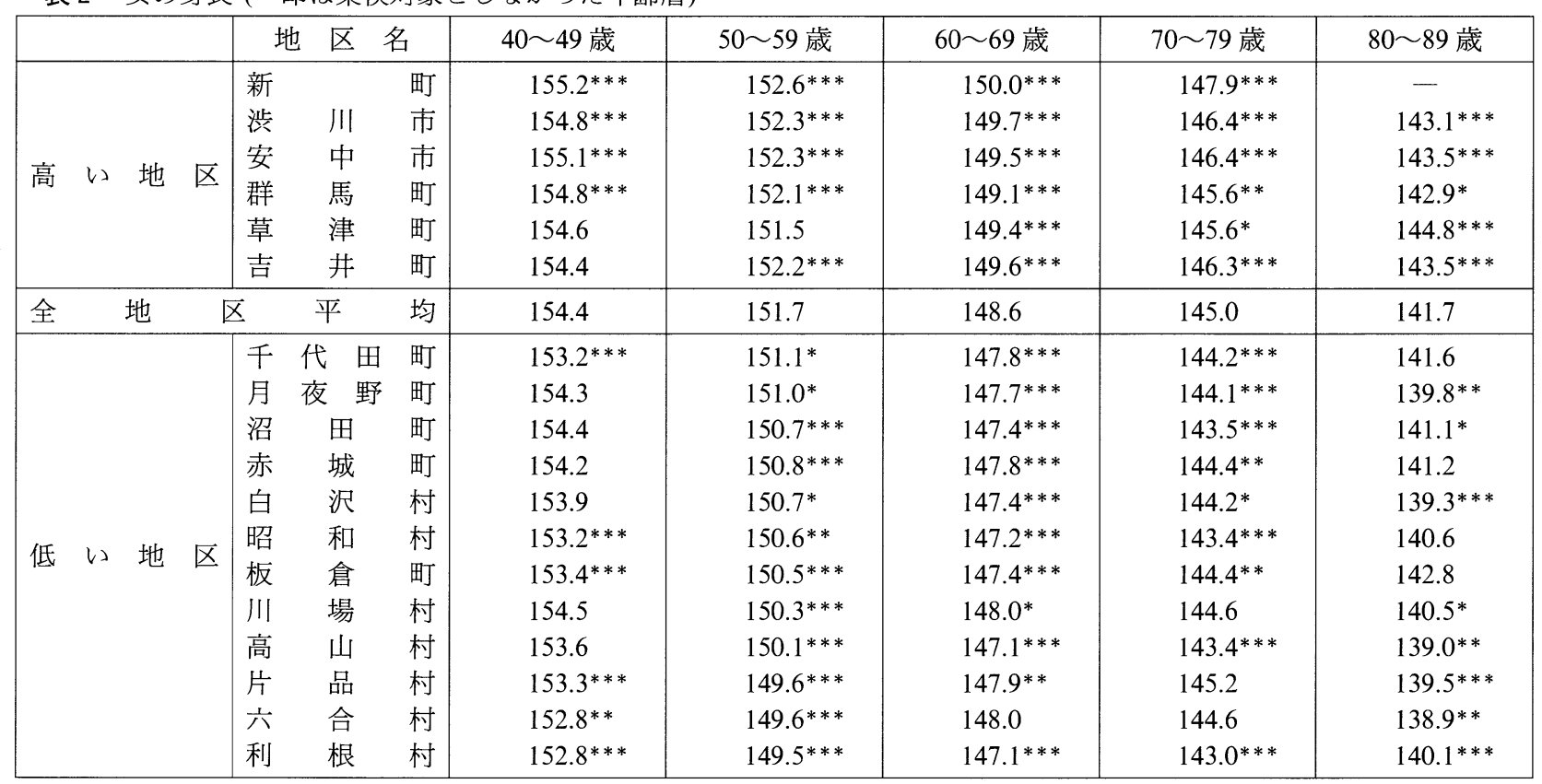

*** $\mathrm{P}<0.003 \quad * * \mathrm{P}<0.01 \quad{ }^{*} \mathrm{P}<0.05$

中市, 新町であり, 男の身長が低い地区では女の身長も 低い。それにしても，全国平均と比べ身長が有意に高い 地区は 80 歳代の草津町女性だけでしかない.

\section{2. 全国平均との比較}

40 歳代から 80 歳以上の各年齢階級について, 昭和 55 年度から平成 8 年度にかけての身長の推移を全国平均と 比較した (図 1). 70 歳以上の身長は平成 5 年度以降しか 得られていないため, 長期間にわたる推移は全国平均と の比較が不可能であるが, 40 歳代〜80 歳以上の何れの 年齢層も群馬県は全国平均より身長が低い.

ここで近年における群馬県の身長を全国平均と比較し た (表 3). その結果, 全国との差は女より男のほうが大で あるが, 男女とも 70 歳代や 80 歳以上の群に比べ 40 歳 代における両者の差は小さい. これは, 身長に影響を与 える社会経済的要因の群馬県と全国との差が過去に逆上 るほど大きかったことを示唆している.

\section{3. 全国平均の年次推移}

国民栄養調査に報告されている 1 歳から 70 歳以上の 各年齢階級別身長 ${ }^{2)}$ について, 昭和 55 年度から平成 8 年 度へかけての 17 年間の推移を検討した. しかし本報告 では各年齢層の被験者数が少なく，とくに近年では 1 〜25 歳で各年齢層の被験者数が 100 名を割っているた め, 観測年度の違いによって平均值にバラツキが大きい. そこで, 昭和 55 年度から平成 8 年度にかけて報告され た身長平均値と観測年度との直線回帰を求め，これを基 礎に平成 8 年度と昭和 55 年度の身長を計算し, 両者の 差ならびに身長の伸び率を検討した.

その結果, 1 歳から 5 歳までは男女ともに有意相関に 乏しく, 男では 17～22 歳, 女では 13〜 15, 20 歳で関連の 度合いは低く, 身長の伸び率も小さい (表 4). この点につ いては, 昭和 55 年以降では新生児から乳幼児にかけて の身長の伸びに影響する要因にはほとんど変化がないこ 


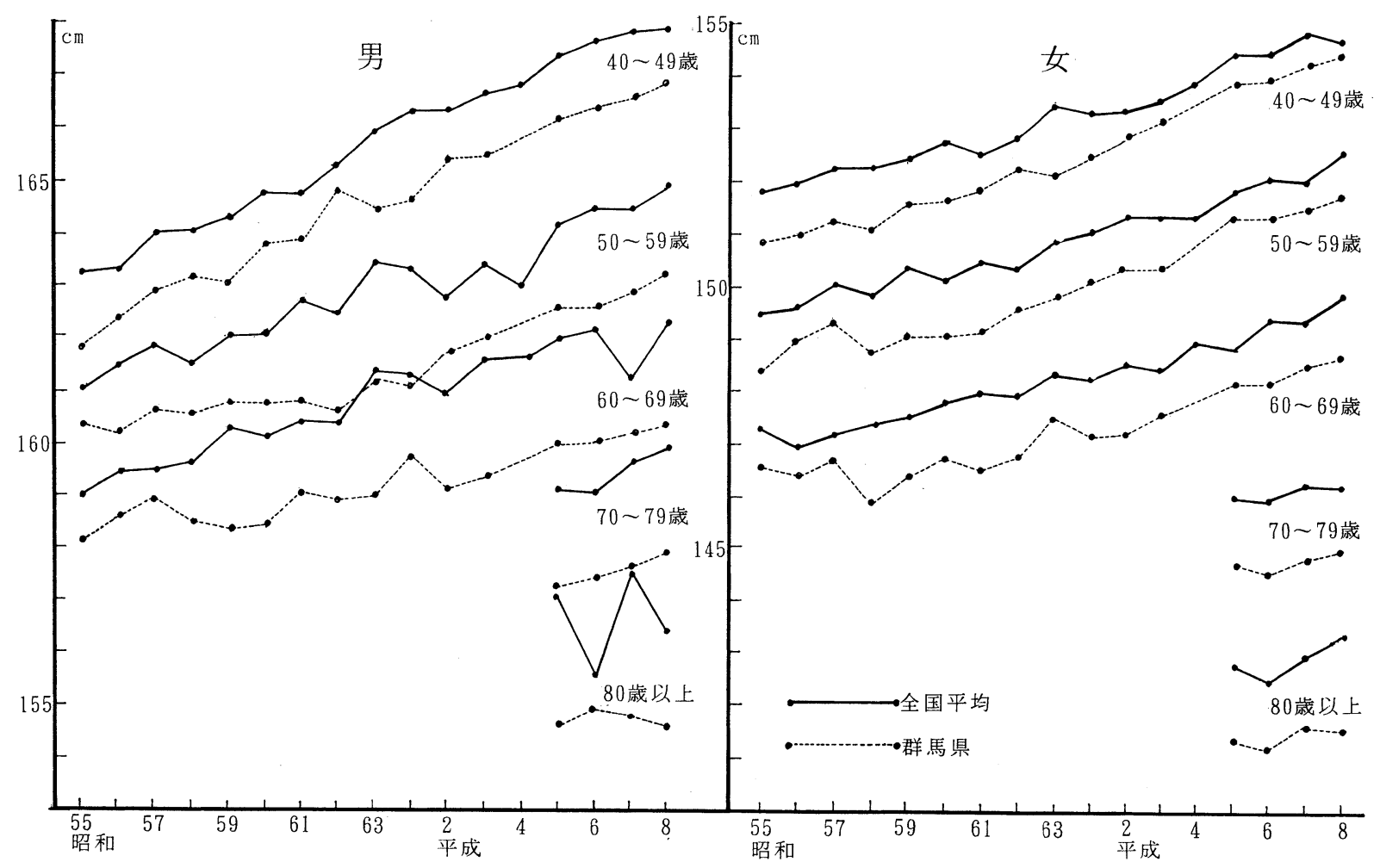

図 1 身長の年次推移

表 3 近年における群馬県民の身長と全国平均との差

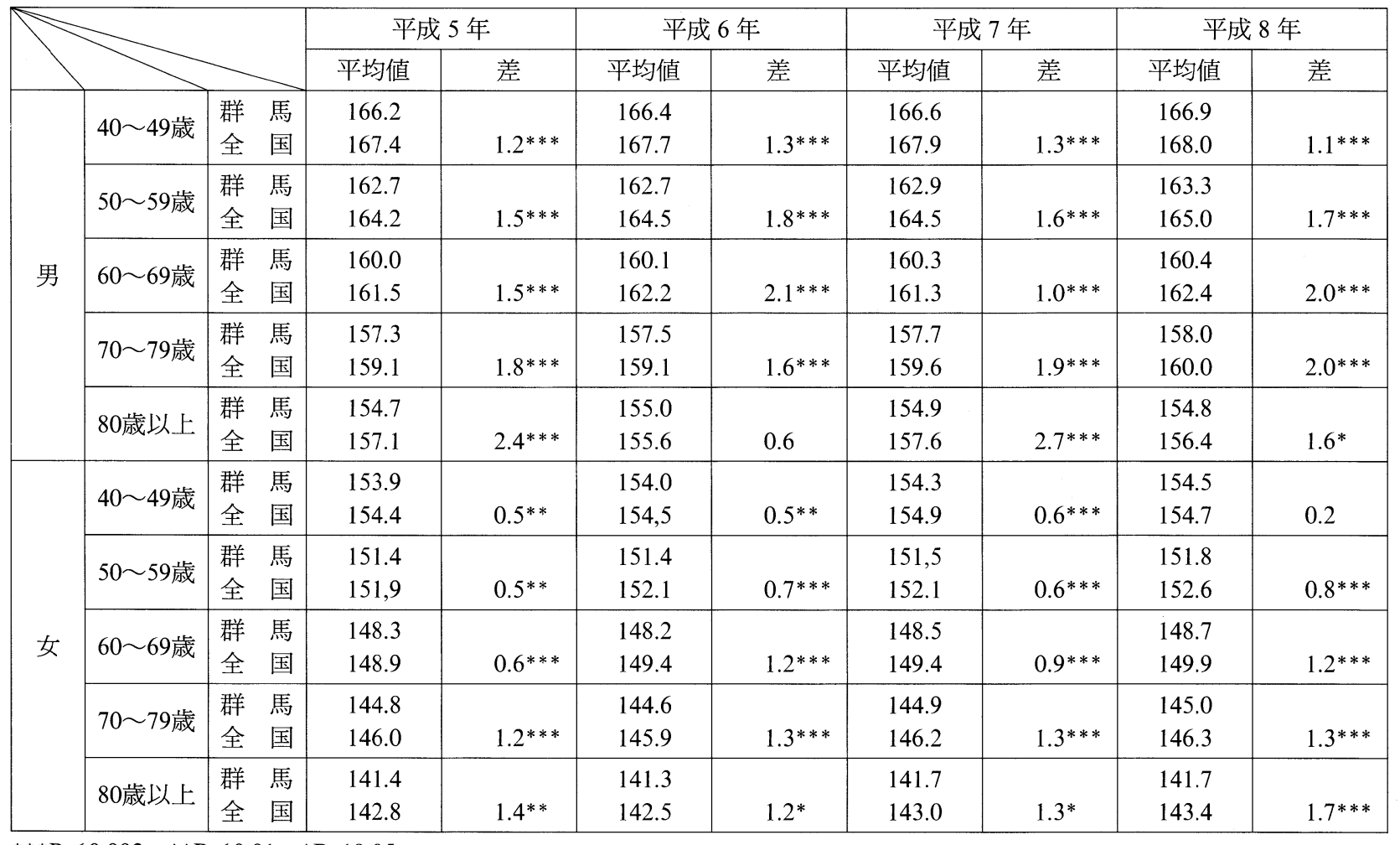

***P $<0.003 \quad * * \mathrm{P}<0.01 \quad * \mathrm{P}<0.05$

とを示唆しているのかも知れない. しかし，そのほかの 年齢層で一部に有意性を示さない成績がみられる点につ いては, 主として測定年度の違いによる身長平均值のバ ラツキが大きかったことに理由があるものと思われる.
ところで 30 歳代以降は身長の伸び率が大きく，男では 40 歳代, 女では 30 歳代に最も大きい伸び率がみられて いる. なお男では 25 歳以降, 女では 24 歳以降の身長が 順次低くなっているのは, この年齢以降の者たちは身長 
表 4 昭和 55 年度から平成 8 年度に至る年度と身長との相関係数, 計算上の平成 8 年度身長, 昭和 55 年度との差, 伸び率

\begin{tabular}{|c|c|c|c|c|c|c|c|c|}
\hline \multirow{3}{*}{$\begin{array}{l}\text { 年齢 } \\
\text { (歳) }\end{array}$} & \multicolumn{4}{|c|}{ 男 } & \multicolumn{4}{|c|}{ 女 } \\
\hline & \multirow{2}{*}{$\begin{array}{l}\text { 年度と身長と } \\
\text { の相関係数 }\end{array}$} & \multicolumn{3}{|c|}{ 計 算上の值 } & \multirow{2}{*}{$\begin{array}{l}\text { 年度と身長と } \\
\text { の相関係数 }\end{array}$} & \multicolumn{3}{|c|}{ 計 算上の值 } \\
\hline & & 身長 (cm) & 差 (cm) & 伸び率 & & 身長 (cm) & 差 (cm) & 伸び率 \\
\hline 1 & 0.077 & 80.48 & 0.11 & $0.14 \%$ & -0.111 & 78.92 & -0.15 & $-0.19 \%$ \\
\hline 2 & 0.216 & 89.58 & 0.37 & $0.41 \%$ & 0.123 & 88.42 & 0.18 & $0.20 \%$ \\
\hline 3 & 0.415 & 97.12 & 0.64 & $0.66 \%$ & -0.091 & 95.61 & -0.11 & $-0.12 \%$ \\
\hline 4 & $0.621^{*}$ & 104.04 & 0.84 & $0.82 \%$ & $0.660^{*}$ & 103.27 & 1.01 & $0.99 \%$ \\
\hline 5 & 0.211 & 109.45 & 0.03 & $0.39 \%$ & 0.445 & 109.49 & 0.78 & $0.72 \%$ \\
\hline 6 & $0.574^{*}$ & 116.35 & 0.92 & $0.80 \%$ & $0.579^{*}$ & 115.72 & 1.15 & $1.01 \%$ \\
\hline 7 & $0.720^{* *}$ & 122.31 & 1.59 & $1.32 \%$ & $0.679^{*}$ & 121.67 & 1.30 & $1.08 \%$ \\
\hline 8 & $0.539 *$ & 127.71 & 1.22 & $0.96 \%$ & $0.622^{*}$ & 127.43 & 1.57 & $1.34 \%$ \\
\hline 9 & $0.671^{* *}$ & 132.83 & 1.40 & $1.07 \%$ & $0.696^{* *}$ & 133.51 & 2.17 & $1.65 \%$ \\
\hline 10 & $0.768^{* * *}$ & 138.70 & 2.04 & $1.49 \%$ & $0.675^{* *}$ & 139.55 & 1.84 & $1.34 \%$ \\
\hline 11 & $0.786^{* * *}$ & 144.60 & 2.18 & $1.53 \%$ & $0.638^{*}$ & 146.68 & 2.21 & $1.53 \%$ \\
\hline 12 & $0.738 * * *$ & 151.78 & 2.83 & $1.90 \%$ & $0.798 * * *$ & 151.96 & 2.12 & $1.41 \%$ \\
\hline 13 & $0.799 * * *$ & 158.84 & 2.45 & $1.56 \%$ & $0.609^{*}$ & 154.85 & 1.02 & $0.66 \%$ \\
\hline 14 & $0.794 * * *$ & 164.41 & 1.53 & $0.94 \%$ & 0.504 & 156.36 & 0.95 & $0.61 \%$ \\
\hline 15 & $0.807^{* * *}$ & 168.08 & 1.85 & $1.11 \%$ & 0.574 & 157.69 & 1.78 & $1.14 \%$ \\
\hline 16 & $0.791^{* * *}$ & 170.05 & 2.18 & $1.30 \%$ & $0.692 * *$ & 157.76 & 1.25 & $0.80 \%$ \\
\hline 17 & $0.542 *$ & 170.77 & 1.39 & $0.82 \%$ & $0.559^{*}$ & 157.91 & 1.25 & $0.80 \%$ \\
\hline 18 & $0.611^{*}$ & 171.38 & 1.71 & $0.10 \%$ & $0.689 * *$ & 158.59 & 1.99 & $1.28 \%$ \\
\hline 19 & 0.473 & 171.44 & 1.40 & $0.83 \%$ & $0.578^{* *}$ & 158.25 & 1.32 & $0.84 \%$ \\
\hline 20 & 0.300 & 170.79 & 0.70 & $0.41 \%$ & 0.492 & 158.09 & 1.33 & $0.85 \%$ \\
\hline 21 & $0.630^{*}$ & 171.41 & 1.76 & $1.04 \%$ & $0.847 * * *$ & 158.57 & 2.53 & $1.62 \%$ \\
\hline 22 & $0.508^{*}$ & 170.94 & 1.31 & $0.77 \%$ & $0.742 * *$ & 158.31 & 1.94 & $1.24 \%$ \\
\hline 23 & $0.752 * * *$ & 171.74 & 2.59 & $1.53 \%$ & $0.848^{* * *}$ & 158.55 & 2.77 & $1.78 \%$ \\
\hline 24 & $0.858^{* * *}$ & 172.38 & 3.82 & $2.26 \%$ & $0.627^{*}$ & 158.14 & 2.03 & $1.30 \%$ \\
\hline 25 & $0.814^{* * *}$ & 171.82 & 3.08 & $1.82 \%$ & $0.641^{*}$ & 157.91 & 1.71 & $1.10 \%$ \\
\hline $26 \sim 29$ & $0.918^{* * *}$ & 171.25 & 3.07 & $1.82 \%$ & $0.940 * * *$ & 158.04 & 2.99 & $1.93 \%$ \\
\hline $30 \sim 39$ & $0.988 * * *$ & 170.56 & 4.42 & $2.66 \%$ & $0.991^{* * *}$ & 157.13 & 3.68 & $2.40 \%$ \\
\hline $40 \sim 49$ & $0.993^{* * *}$ & 168.25 & 5.09 & $3.12 \%$ & $0.984 * * *$ & 154.80 & 3.05 & $2.01 \%$ \\
\hline $50 \sim 59$ & $0.957 * * *$ & 164.66 & 3.47 & $2.15 \%$ & $0.984^{* * *}$ & 152.36 & 2.89 & $1.93 \%$ \\
\hline $60 \sim 69$ & $0.935^{* * *}$ & 162.12 & 2.80 & $1.76 \%$ & $0.981^{* * *}$ & 149.60 & 2.65 & $1.80 \%$ \\
\hline $70 \sim$ & $0.934^{* * *}$ & 159.06 & 2.40 & $1.53 \%$ & $0.966^{* * *}$ & 145.50 & 2.94 & $2.06 \%$ \\
\hline
\end{tabular}

${ }^{* * *} \mathrm{P}<0.01 \quad{ }^{* *} \mathrm{P}<0.02 \quad{ }^{*} \mathrm{P}<0.05$

表 5 年齢別身長の全国平均と群馬県との比較 (平成 7〜9 年度成績3,4) 一括)

\begin{tabular}{|c|c|c|c|c|c|c|c|c|}
\hline \multirow{3}{*}{ 年歯 } & \multicolumn{4}{|c|}{ 男 } & \multicolumn{4}{|c|}{ 女 } \\
\hline & \multicolumn{2}{|c|}{ 全 国 平 均 } & \multicolumn{2}{|c|}{ 群 馬 県 } & \multicolumn{2}{|c|}{ 全 国 平 均 } & \multicolumn{2}{|c|}{ 群馬 } \\
\hline & 平均值 $(\mathrm{cm})$ & 前年齢との差 & 平均値 $(\mathrm{cm})$ & 前年齢との差 & 平均值 $(\mathrm{cm})$ & 前年歯令との差 & 平均值 $(\mathrm{cm})$ & 前年齢との差 \\
\hline 5 & 110.53 & & 110.73 & & 110.07 & & 109.93 & \\
\hline 6 & 116.73 & 6.20 & 116.83 & 6.10 & 115.93 & 5.86 & 116.10 & 6.17 \\
\hline 7 & 122.53 & 5.80 & 122.73 & 5.90 & 121.73 & 5.80 & 121.73 & 5.63 \\
\hline 8 & 128.20 & 5.67 & 128.17 & 5.44 & 127.60 & 5.87 & 127.83 & 6.10 \\
\hline 9 & 133.47 & 5.27 & 133.73 & 5.56 & 133.53 & 5.93 & 133.50 & 5.67 \\
\hline 10 & 138.90 & 5.43 & 139.20 & 5.47 & 140.23 & 6.70 & 140.20 & 6.70 \\
\hline 11 & 144.93 & 6.03 & 145.17 & 5.97 & 146.87 & 6.64 & 147.07 & 6.87 \\
\hline 12 & 152.13 & 7.20 & 152.00 & 6.83 & 152.00 & 5.13 & 152.10 & 5.03 \\
\hline 13 & 159.63 & 7.50 & 159.63 & 7.63 & 155.10 & 3.10 & 155.37 & 3.27 \\
\hline 14 & 165.20 & 5.60 & 165.27 & 5.64 & 156.73 & 1.63 & 156.60 & 1.23 \\
\hline 15 & 168.47 & 3.27 & 168.37 & 3.10 & 157.37 & 0.64 & 157.43 & 0.83 \\
\hline 16 & 170.03 & 1.56 & 169.93 & 1.56 & 157.87 & 0.50 & 158.00 & 0.57 \\
\hline 17 & 170.87 & 0.84 & 170.77 & 0.84 & 158.03 & 0.16 & 158.10 & 0.10 \\
\hline
\end{tabular}



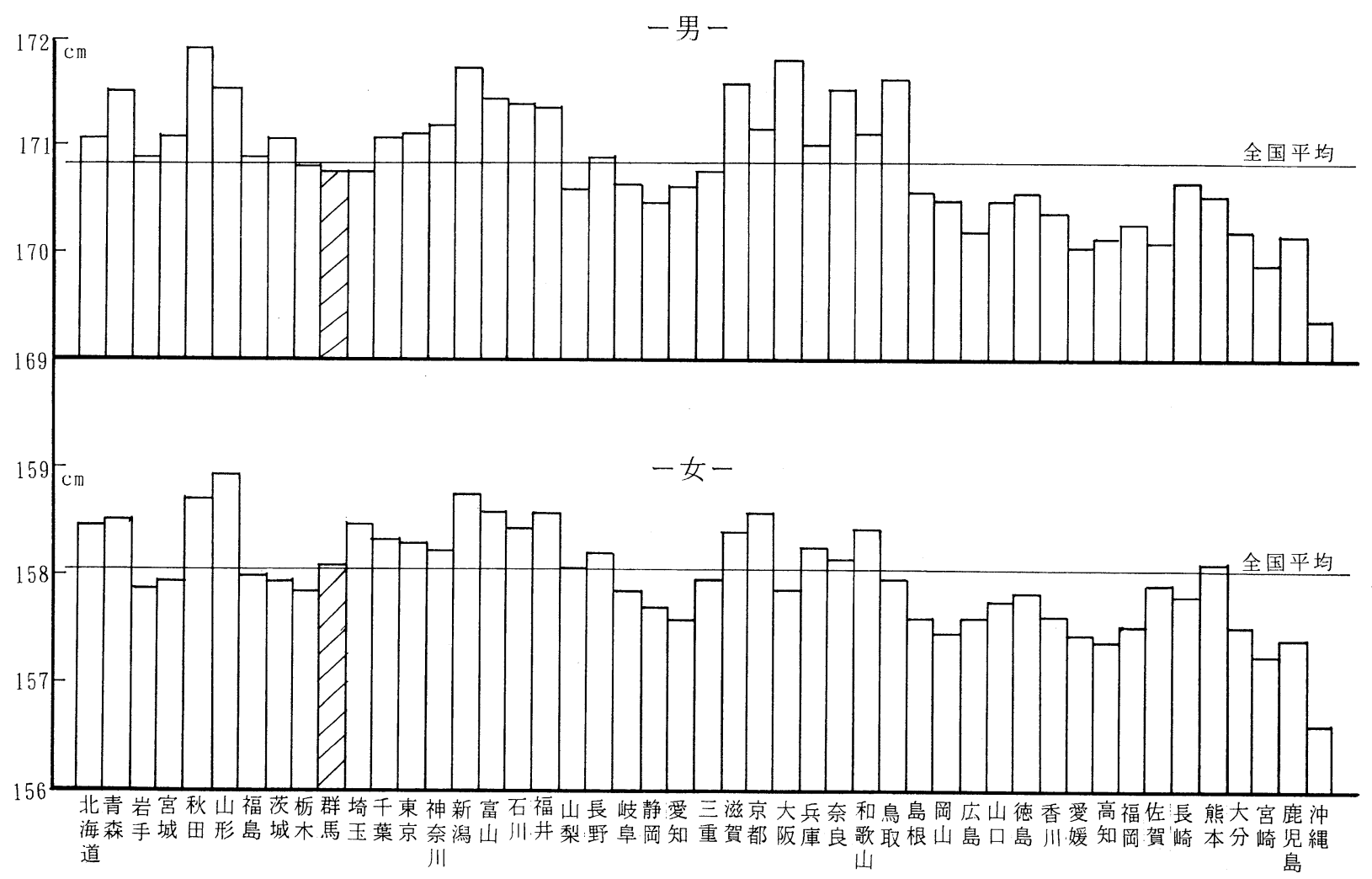

図 2 都道府県別・17 歳身長

表 6 身長と気象との相関係数

\begin{tabular}{|c|c|c|c|c|c|c|}
\hline & \multicolumn{3}{|c|}{ 男 } & \multicolumn{3}{|c|}{ 女 } \\
\hline & 平均気温 & 日照時間 & 降雪日 数 & 平均気温 & 日照時間 & 降雪日 数 \\
\hline 歳 & $-0.762 * *$ & $-0.535^{* *}$ & $0.689 * *$ & $-0.754^{* *}$ & $-0.480^{*}$ & $0.689 * *$ \\
\hline 歳 & $-0.723^{* *}$ & $-0.437^{* *}$ & $0.623^{* *}$ & $-0.793^{* *}$ & $-0.522^{*}$ & $0.758^{* *}$ \\
\hline 歳 & $0.728 * *$ & $-0.482^{*}$ & $0.645^{* *}$ & $-0.728^{* *}$ & $-0.520^{*}$ & $0.703^{* *}$ \\
\hline 歳 & $-0.775^{* *}$ & $-0.548^{* *}$ & $0.707^{* *}$ & $-0.751^{* *}$ & $-0.578^{* *}$ & $0.753^{* *}$ \\
\hline 歳 & $-0.814^{* *}$ & $-0.585^{* *}$ & $0.727^{* *}$ & $-0.630^{* *}$ & $-0.535^{* *}$ & $0.712^{* *}$ \\
\hline 10 歳 & $-0.779 * *$ & $-0.497^{*}$ & $0.701^{* *}$ & $-0.673^{* *}$ & $-0.557^{* *}$ & $0.748^{* *}$ \\
\hline 歳 & $-0.765^{* *}$ & $-0.486^{* *}$ & $0.741^{* *}$ & $-0.600 * *$ & $-0.536^{* *}$ & $0.664^{* *}$ \\
\hline 歳 & $-0.720^{* *}$ & $-0.514^{*}$ & $0.736^{* *}$ & $-0.583^{* *}$ & $-0.567^{* *}$ & $0.599 * *$ \\
\hline 歳 & $-0.697 * *$ & $-0.507^{*}$ & $0.749 * *$ & $-0.616^{* *}$ & $-0.542 * *$ & $0.523^{* *}$ \\
\hline 歳 & $-0.696^{* *}$ & $-0.595^{* *}$ & $0.684^{* *}$ & $-0.601^{* *}$ & $-0.596^{* *}$ & $0.563^{* *}$ \\
\hline 歳 & $-0.588^{* *}$ & $-0.503^{*}$ & $0.497^{*}$ & $-0.620^{* *}$ & $-0.436^{* *}$ & $0.465^{*}$ \\
\hline 歳 & $-0.550^{* *}$ & $-0.566^{* *}$ & $0.520^{*}$ & $-0.530^{* *}$ & $-0.468^{* *}$ & $0.447^{*}$ \\
\hline 歳 & $-0.562 * *$ & $-0.604^{* *}$ & $0.508 *$ & $-0.642 * *$ & $-0.544 * *$ & $0.556^{* *}$ \\
\hline
\end{tabular}

の伸びが既に終了しており，彼らが伸び盛りの頃の社会 経済的背景が現時点に比べ劣っていたことを示唆するも のと思われる.

\section{4. 児童・生徒の身長}

群馬県の身長を全国平均と比較する資料には 5 歳 (幼 稚園児) から 17 歳 (高校生) までの身長を追及している 学校保健統計調査 ${ }^{3,4)}$ がある. その平成 7～9 年度成績を 一括して両者の比較検討を行った. 全国でも当県でも被 験者数を発表していないため推計学上の有意性は検討で
表 717 歳身長に対する説明変量の標準偏回帰係数 (*印は 偏回帰係数の有意性) と自由度調整決定定数

\begin{tabular}{|c|c|c|c|}
\hline & 平均気温 & 日照時間 & 息由度調整 \\
\hline 男 & $-5.8 \mathrm{E}-3^{*}$ & $-1.2 \mathrm{E}-6^{*}$ & $0.4558^{*}$ \\
女 & $-6.5 \mathrm{E}-3^{*}$ & $-7.6 \mathrm{E}-7^{*}$ & $0.4802^{*}$ \\
\hline
\end{tabular}

きないが, 群馬県と全国平均との間にはほとんど差がな いと思われる (表 5).つまり身長が伸び盛りの年齢層で, 群馬県の身長が全国平均と大差がないということは, 当 
県民の成人以降の身長が将来は全国並みに達することを 暗示している.

ところで身長の伸びが著しい年齢は，男では全国平均 も群馬県も 12〜13 歳間，女では全国平均では 9〜10 歳 間, 群馬県では 10〜11 歳間である.

ここで平成 7〜9年度を一括した 17 歳の身長を都道府 県別にみると, 男女ともに身長が高いのは秋田, 山形, 新 潟が代表で，島根県以西は軒並みに身長が低く，とくに 沖縄県の身長は最も低い (図 2).この実態の背景を都道 府県の気象状況5,6) から検討したところ，5歳から 17 歳 にかけての何れの年齢層も，身長は年間の平均気温と日 照時間とは負，降雪日数とは正の有意相関を呈していた (表 6). 試みに 17 歳身長を重回㷌分析してみると，身長 に大きく影響するのは平均気温である (表 7).

\section{考察}

群馬県民の身長を論ずるにあたつては, 調查対象と なった被験者が，成長期を群馬県内で迎えたことが前提 条件である. 本調查はそこまで厳密な条件づけをしてい ないが, 大都市と違って被験者の大半は現在の地区に永 住しているものと仮定して検討をすすめた。

まず県内各地区に扔ける 40 歳以上の年齢別身長を全 地区平均と比較し, 身長が高い地区と低い地区があるこ とを明らかにした。しかし身長が高いといっても，全国 平均を有意に上回っているのは 80 歳代の草津町女性だ けでしかない。ところで県内各地区の身長は男女とも1 人あたりの年間所得と有意の正相関を示しているが77, 本報告は群馬県下 70 市町村全域にわたる調查ではない。 もし高所得地区の前橋市, 高崎市, 伊勢崎市の資料を加 えれば，全国平均身長を上回る地区が増えるのではなか ろうか.

なお，標高が高い地区では出生時ならびにその後の発

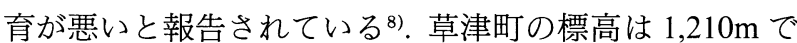
県内では最も高いが，この程度の標高では身長への影響 はないという結果であった。

ところで 40 歳以上の身長を全国平均と比較してみる と, 40 歳代にお では両者の差の開きが大きい.これは過去に逆上るほど 身長に影響を与える社会経済的要因が群馬県では全国平 均より劣っていたことを示唆する成績である. それはそ れとして，身長の伸びが終了したはずの年齢層でも暦年 身長が高くなっているのは，身長の伸びに恵まれた時代 の者たちが次々に加わる一方で, 同じ年齢層のなかでも 身長が低い者たちが次の年齢階級へ送り出される結果で ある. な抢高齢者層の身長が低いことに関しては, 脊椎 弯曲や椎間板圧縮による生理学的減少が加わっていよ
う.

ここで国民栄養調査の資料で，思春期以降の身長が一 時的に伸び悩んでいる成績については, 測定年度の違い による身長平均值のバラツキに理由がある。これについ ては，この年齢層では身長の伸び年齢が早い者と遅い者 とが錯綜している影響という見方もあろうが，実際に標 準偏差が増大している年齢は男で 12〜13 歳, 女で 10 ～11 歳となっている2). つまりこれは単に被験者数が少 なかった影響と考えられる。

なお学校保健統計調查によると, 身長が最も伸びる年 歯恰，各都道府県すべて，男では 11〜 13 歳間，女では 9 〜1 歳間である ${ }^{3)}$. この点に関しては, 国際的には男が平 均 13.5 歳, 女が平均 11.7 歳であると報告されている9). ここで前半期 (男では 11〜12 歳間, 女では 9～10 歳間) の伸びと後半期 (男では 12〜13 歳間, 女では 10〜 11 歳 間) の伸びを比較したところ, 前半期の伸びが後半期の 伸びを上回る地区は, 47 都道府県のうち男で 10 地区, 女 で 23 地区ある. つまり, これらの地区では思春期の到来 が早いことを暗示している。一般に思春期を早く迎えた 者の最終身長は低いことが知られているので, 17 歳身長 が全国平均と $3 \mathrm{~mm}$ 以上の差を呈している男 29 地区, 女 26 地区を選び，身長の伸びが早い地区は 17 歳身長が低 いかどうかを検討した，その結果，オッズ比は男が 5.45, 女が 1.87 であったが, 対象地区数が少ないため有意性は 見られない. この点に関しては, 後半期の伸び/前半期の 伸びと，17歳身長との相関係数を求めたが，男が 0.163 , 女が 0.01 で, 両者間の関連は示されなかった.

さて当県では, 5 歳から 17 歳にかけての身長を調查年 度と 30 年前 (親の子供時代) と暦年比較している. これ によると, 男では 13 歳, 女では 11 歳の身長が 30 年前に 比べ最も伸びが大きいが，近年に至るほどその差は小さ くなっている ${ }^{4)}$.これは昭和 30 年代から昭和 50 年代に かけての身長の伸びが顕著であった ${ }^{4)}$ ところに理由があ る.

一般に, 身長は思春期開始から急速に伸びはじめ, 伸 び率は約 2 年後に最大に達する. 乳幼児期には栄養, そ の後, 思春期までは成長ホルモン, 思春期からは性ホル モンが大きく関与することが知られているが，その背景 には栄養のほか各種の環境因子とくに社会経済的因子が 潜んでいよう。

さて昭和 55 年度から平成 8 年度にかけての身長の推 移をみると, 男では 40 歳代, 女では 30 歳代で身長の伸 びが最大を呈しているが, 現在 40 歳代の者たちが生ま れたのは昭和 24 年から昭和 33 年にかけてである.この 点に関しては，日本人の身長が急速に伸び始めたのは 1947 年 (昭和 22 年) 以降であることが国際的に評価さ 
れている ${ }^{9}$.ところで，身長の伸びに関与する社会経済的 因子のなかで, 大きな影響を与えるのは食生活水準であ ると考えられる. とくに思春期の身長増加に重要な因子 であるインスリン様成長因子の血中濃度は, 低カロリー 群よりは高カロリー群のほうが，摂取カロリーが同じで も摂取蛋白質量が多い群に高值であることが知られてい る.

ところで本邦の蛋白質摂取量は昭和 21 年以降きわめ て徐々に増えつつあったが, 昭和 40 年前半から後半に かけて急速に増加し，その後も漸増している，とくに動 物性蛋白質の摂取状況は, 昭和 30 年の後半から昭和 40 年の後半にかけて急速に増え，その後も現在にかけて漸 増を続けている2). 群馬県の栄養摂取状況については, 昭 和 56 年から平成元年まで調査し続けてきた。これによ ると, 昭和 58 年までは当県の動物性蛋白質摂取量は全 国平均より明らかに劣っていた ${ }^{10)}$. 成人以降における群 馬県民の身長が全国平均より低く，児童・生徒の身長が 全国平均並になっている理由の一つは, 栄養摄取の改善 によるものと思われる。

ここで昭和 55 年度から平成 8 年度までの国民栄養調 査の資料でみると，それぞれの年度における最大の身長 は男が 19〜24 歳, 女が 18〜23 歳であった ${ }^{2)}$. ただしこの 調査では被験者数が少ないため, 調査年度ごとの数值に バラツキが目立つ.そこで今回の報告では，この期間に 示された身長平均值と測定年度との直線回帰を求め，こ れを基礎に平成 8 年度の身長を算出した。その結果，最 大身長は男が 24 歳の $172.4 \mathrm{~cm}$, 女が 21 歳の $158.6 \mathrm{~cm}$ と なる.さて今後，食文化を含めた社会環境の向上により， 日本人の身長はどこまで伸びるのであろうか。もちろん 身長には，社会環境因子のほか民族的遺伝因子が背景に 関与している. 同じ日本国民であるのに沖縄県民の身長 が低い背景には, 遺伝因子が強く関与している可能性も ある。

なお世界19集団の調査では，米国，オランダ，ス ウェーデンが高身長国であり，グアテマラが低身長国と 評価されている ${ }^{9)}$.

さてノルウェーでは, 身長と全死亡率とは逆相関, つ まり身長が低い者ほど全死亡率は高いことが報告されて いる11)。これは低身長者の背景に社会経済的因子や成長 期の疾病が関与しているためとも考えられる．この点に 関しては, 本邦における超高齢者率 (「90 歳以上人口」： $\lceil 65$ 歳以上人口」× 100$)$ に対して 14 歳身長が, 男女とも に最も深い負の関連を示していることを重回帰分析で明 らかとした ${ }^{12)}$. 説明変量としての身長に 14 歳を選んだ理 由は, 当時手元にある都道府県別・身長の資料がこれし かなかったためである.ところで 14 歳身長と 17 歳身長
との相関係数は, 男では 0.845 ,女では 0.933 である. 因に 5 歳身長と 17 歳身長との相関係数は, 男では 0.752 ,女で は 0.765 で, 上記の数值は何れも $\mathrm{P}<0.001$ であるが, 14 歳 身長は 17 歳身長を推測するに十分耐えるものと思われ る. そして 17 歳身長の長短が成人期の身長に反映する と仮定すると，本邦では身長が低い地区では寿命が長い という結果であり，これはノルウェーとは逆の成績であ る. なお 50 歳代の調査で, 当県では身長の高い地区に乳 がんが多い実態を報告ずみである13).

\section{おわりに}

群馬県民の身長は，40 歳以降でみると全国平均より低 いが, 5 歳 (幼稚園児) から 17 歳 (高校生) にかけての身 長は全国平均並みである.これは, いずれ将来, 当県にお ける成人の身長も全国平均並みに達することを暗示して いる. また男女とも 70 歳代以降の群に比べて 40 歳代で 全国平均との身長差が少ない点は, 過去の時代に逆上る ほど群馬県の社会経済的要因が全国と大きく相違してい たことを推測させる.

なお都道府県別にみた 17 歳身長は西低東高の様相を 呈しているが，その背景には気象条件が大きく関与して いることを明らかとした

\section{文献}

1）群馬県成人病研究所：平成 3 年度循環器集団検診報 告書. 平成 4 年; 16.

2）厚生省保健医療局健康増進栄養課監修：国民栄養の 現状. 第一出版, 平成 6 年; 157-158. 平成 7 年; 131 . 平成 8 年；129. 平成 9 年；109，146-147. 平成 10 年; $33,35,103$.

3）文部省大臣官房調査統計課：学校保健統計調査報告 書. 平成 7 年度；19，134-159. 平成 8 年度；17，132157. 平成 9 年度 ; $3,118-143$.

4) 群馬県企画部統計課: 学校保健統計調査結果概要. 平成 7 年度；4, 5. 平成 8 年度；4, 5. 平成 9 年度；3, 6, 12-13.

5）国立天文台：理科年表 平成 8 年. 丸善，平成 7 年; 198-199.

6）総務庁統計局：統計でみる県のすがた 1998. 日本統 計協会, 平成 10 年; 2-3，20-21，38-39，56-57，74-75， 92-93.

7) 高玉真光, 渡辺 孝, 家崎 智, 市村 茂: 集団検診 成績と地区特性. 北関東医誌 1997；47：141-148.

8) Vip R, Binkin NJ, Trowbridge FL. Altitude and child growth. J Pediat 1988 ; 113 : 486-489.

9) Report of a WHO Expert Committee. Physical 
Status: The Use and Interpretation of Anthropometry. Geneva: WHO, 1995 ; 278, 376-386.

10）群馬県成人病研究所・群馬県衛生環境部保険予防課： 集団検診からみた今後の本県における健康づくりへ の提言. 平成 3 年; 33-37.
11）Waaler HT：1984. 文献 9 より引用.

12）高玉真光, 渡辺 孝,家崎 智: 超高歯者率の検討. 北関東医誌 $1999 ; 49$ : 1-8.

13）高玉真光, 渡辺 孝, 家崎 智: 生活習慣病と県勢 との関連. 北関東医誌 $1998 ; 48 ： 351-358$.

\title{
THE HEIGHT OF RESIDENTS OF GUNMA PERFECTURE
}

\author{
Masamitsu Takatama,Takashi Watanabe,Satoru Iesaki*, \\ Shigeru Ichimura** \\ Geriatrics Reseach Institute, Gunma \\ * Gunma Health Foundation \\ **San-ai Kai
}

Districts with taller or shorter resident 40 years of age or over were identified by mass screening examinations in 46 areas in Gunma Prefecture. No district had an average hight that was taller than the Japanese average. The average height of inhabitants in Gunma Prefecture is shorter than the average 40 year-old and over Japanese.

The difference in height between Gunma and the average for Japan decreases, in 40 70 years olds, while the height of $5 \sim 17$ years olds is almost the same. Therefore, the past socio-economic situation seems to have an effect on height and may account for the large gap between the two groups. In the future, the average height of adults in Gunma may reach the Japanese average.

The height of infants in Japan did not increase from 1980 to 1996, indicating that the infant nutrirional state remaind almost the same from 1980 to 1996.

Among 5 17 year old, taller height are found in eastern Japan and shorter height in western Japan, indicating the climate may affect height.

Key words : Height, Epidemiology. 